\title{
nature
}

\section{A clear case for closer European union}

Britain's Labour government has given notice of its opposition to a new European 'superstate'. But the dangers should not obscure the advantages of mutual support in building up Europe's scientific infrastructure.

T here is little doubt that the strength, if not the vitality, of US science is partly due to the way that 50 states of widely differing social and economic characteristics have been able to operate effectively as a single political unit. This has brought significant economies of scale to research. It has also given less advantaged states important help in their efforts to pull themselves up by the bootstraps, allowing them to draw on the support of federal agencies to promote infrastructures for scientific education and research.

This lesson should not be forgotten in Europe. There may be sound political reasons for remaining wary of pressures to create a superstate - Britain's new Prime Minister, Tony Blair, made clear last weekend in one of his first major policy announcements that he is unlikely to differ significantly from his predecessor, John Major, on this issue. But this does not undermine the fact that, as far as science is concerned, closer collaboration and mutual support promise substantial benefits, particularly (although not exclusively) to poorer member states of the European Union (EU).

Some of the evidence of these benefits is already clear. One is the way in which funding from the European Commission has helped to provide researchers from these countries with access to high-cost advanced research facilities which not even the larger countries could afford to construct on their own. Another has been the extensive use made of the EU's so-called 'structural funds' by some of the poorer states, such as Portugal (see page 115), to construct modern, wellequipped national facilities enabling them in principle to participate in international level science.

There are, inevitably, several dangers associated with the use of these funds to promote science. One, as some of the larger contributors to EU funds frequently point out, is that such funding may come to be seen as an alternative to domestic investment in research. This would be a mistake, as it would divorce planning for research and development from other, equally important, dimensions of research policy (for example, the training of scientists and engineers).

A second danger, perhaps more serious for those working in such facilities, lies in the fact that the capital investment from Brussels includes no consideration for future running costs. This leaves the new institutions to compete for what are often highly limited funds with more established bodies, such as universities; some are already threatened with being stranded as expensive white elephants. And there is also the danger that the research programmes of such institutes, if planned outside regular scientific channels perhaps influenced by strong local political factors - may lack adequate quality controls to justify the initial investment.

But all this calls for more European-level involvement, not less. One way that countries such as Portugal have been able to benefit from their membership of the EU is the opportunity that this has created to raise scientific standards by opening up research programmes to scrutiny by European peers. The more common agreement that can be reached across Europe on how investment in research can produce high quality, cost-effective results, the easier it will be to justify an increase in this investment, and the more productive it is likely to be.

Next week, Europe's research ministers meet to give their first opinion on the commission's proposals for the next multi-year Framework research programme. Inevitably, the ministers will face domestic pressures to interpret the concept of cost-effectiveness in a narrow, economic sense. But hopefully they will be sufficiently enlightened to accept that building what some have described as a 'scientific Europe' - in which all EU states are active participants and the richest feel a responsibility to extend a helping hand to the poorest — is both a desirable and a feasible objective.

\section{Red tape must not strangle good science}

The reaction to a tritium leak on Long Island threatens US government laboratories with the last thing they need.

$\square$ ederico Peña, the US energy secretary, has sacked the contractor at Brookhaven National Laboratory on Long Island, New York, accusing the management there of trading off the conduct of good research against the maintenance of high environmental standards (see page 114). Eliminating such a trade-off is certainly a laudable goal. But it is hard to believe that the dismissal of the Brookhaven contractor will do much to achieve it. More likely, it will reduce the prospects for the cost-effective conduct of top quality research by imposing yet more oversight, review and regulation on the Department of Energy's laboratories. That is the last thing they need, as Bob Galvin observed in his landmark report on laboratory reform.

The energy department's attempt to make up for past errors at Brookhaven involves the preparation of so many reviews and studies that it is hard to believe that anyone there will be left free to do anything else. It has also shut Brookhaven's research reactor, agreed to the early departure of Nick Samios - as talented and communicative a director as any of its laboratories has ever had - and now sacked the contractor. All this because a monitoring project that Brookhaven planned in 1995 took place 18 months late, having failed to win enough priority points. As a result, a small — some would say insignificant — leak of tritium went undetected for that length of time.

It would have been too much to ask that Peña, on his visit to Long Island last week, should have sought to turn public attention to the diminutive nature of the public health risk posed by the Brookhaven leak. But, with brain research from the laboratory, published two weeks ago (see Nature 386, 827-833; 1997), adorning the latest cover of Time magazine, he did at least find time to praise the laboratory's scientific track record. Hopefully the performance of good science will remain the principal criterion by which the energy department judges management at its laboratories. 